\title{
COLLOQUIAL LEXEMES IN JOURNALISTIC TEXTS
}

\author{
LUCIA JASINSKÁ \\ Department of Slovak Studies, Slavonic Philologies, and Communication \\ Faculty of Arts, P. J. Šafárik University in Košice, Slovakia
}

JASINSKÁ, Lucia: Colloquial lexemes in journalistic texts. Journal of Linguistics, 2019, Vol. 70, No 2, pp. 139 - 147.

\begin{abstract}
In our paper we mainly focus on the research of colloquial lexical units in journalistic texts. The aim of the research is colloquiality as a marked attribute of journalistic texts. At first we define the terms hovorovost' (colloquiality) (also in relation to the term hovorenost' (spokenness)) and hovorový(colloquial). Since the point was the research of "living language" - represented by field of journalism - our source material were journalistic texts from the database of the Slovak National Corpus. The number of occurrence of colloquial lexical units was recorded according to their absolute frequency and the results were categorized and interpreted. The most frequented means of expression were verified in current lexicographic processing and the changes of the indicator of colloquiality was studied. With style parameters in background, we evaluated the markedness of the vocabulary of analyzed journalistic texts.
\end{abstract}

Keywords: corpus linguistics, corpus lexicography, dialect corpora

\section{INTRODUCTION}

Journalistic texts have currently an important place in the sphere of social communication. Their primary mission is to inform the addressees of various social layers, age, and education as quickly and accurately as possible. The authors of journalistic texts should represent social events in a semantically unambiguous and understandable way as to their expression aspect. The field of journalism may be considered the most flexible, most dynamic, and most formative phenomenon of the present, which is being developed and modified even in connection with the use of intralingual, especially lexical, means.

\section{THEORETICAL BACKGROUND}

In the present paper, we will focus on colloquial lexemes in journalistic texts. In the introduction to this paper, we consider it necessary - even with regard to the definition of variance in linguistics - to define the term hovorovost' (colloquiality) (also in relation to the term hovorenost' (spokenness), as these two partially overlap). 
The language notion of hovorový (colloquial) refers to words that are "characteristic of ordinary unofficial verbal manifestations" [13, p. 161] or by using its attribute form in the combination of colloquial style of the standard language we mean the so-called "ordinary communication" (ibid.).

Hovorený (spoken) is said to be the one "which is expressed in its audial form, oral: utterance; spoken form of standard Slovak [13, p. 160]. This is then such a materialization of language that may be perceived as verbal or oral. We consider verbal manifestations made in writing its counterpart.

Colloquiality as now a linguistic term is "the property of the means of language (audial, morphological, lexical, syntactic ones) resulting from their attachment to spoken, unofficial, spontaneous, and usually oral utterances" [13, p. 160]. Several linguists have addressed the meaning of the above key words. ${ }^{1}$

In connection with the concept of colloquiality, J. Bosák contemplates a kind of reflection of the social situation in language consisting in "increasing the utterances in standard communication" and also in the "ever wider and deeper effect of the means of mass communication" [2, p. 65]. As stated by the author, the term colloquiality may be understood as a functional language style, the colloquial lexicon, or the colloquial layer within the vocabulary, but also the means of colloquiality. From the point of view of language stratification, colloquial units, including colloquial language, are included herein.

In her reflections, M. Ivanová-Šalingová [7] identifies the notions of hovorenost' (spokenness) and hovorovost' (colloquiality) when she characterizes colloquial Slovak as a spoken form of standard language. Contrary to that, $\breve{S}$. Peciar considers this statement to be unsatisfactory, as it concerns the identification of the colloquial style of standard Slovak with the spoken form of the standard language. As stated by the author, colloquial style is one of the basic functional language styles that may be characterized as a "purposeful selection and arrangement of those standard means (lexical, word-forming, grammatical, and phonetic ones) that are employed by active users of standard language in utterances in everyday language communication, in the milieu of friends and family" [10, pp. 47-48].

Systematic approach to this issue is applied by J. Findra who classifies the colloquial style developing on the basis of the national language as a model structure of colloquial texts and identifies it by such properties as being of private, unofficial, verbal, and dialogical nature which imply the addressee's presence and communicative function. Of course, the domain of colloquial acts of communication is to be found in the private milieu and in the oral form of their language materialization [5]. In this paper, we identify ourselves with the narrower definition

${ }^{1}$ Some linguists' views on defining the notions of spokenness, colloquiality, and colloquial style are only categorized with a view to the limited scope of the paper. 
of the colloquial style (as suggested by Bosák [2]) as one of the forms by which manifestations are materialized in the common communication sphere.

Confrontation of the notions of common spoken language and colloquial style also appears to be a constructive element in defining colloquiality and colloquial means in communication (including the media one). Colloquiality with a differentiated degree of representation in individual acts of communication may then be perceived as a manifestation of the dynamism of language and its individual spheres. The framework of colloquiality is also enhanced by colloquial lexical means of expression.

Colloquial lexemes make up the basic component in the vocabulary of colloquial style. This is an inventory of language units used primarily in "privatecommunication oral language manifestations" [5, p. 55]. J. Findra defines here properties such as spontaneity, privacy, dialogical and unofficial nature, and situational anchoring of utterance. While these are typical means of expression in oral private acts of communication, they are not used in written texts, especially not in those of educational or administrative type. More specifically, they should not be used there or their use would have to be well founded and functional.

In this paper, we analyse lexical means in the texts of mostly journalistic style, which finds its space in the media product environment, whereby these are "not just newspapers, but nowadays also radio, television, and journalistic film" [9, p. 459] and we add that in the $21^{\text {st }}$ century even the Internet environment should be included.

According to J. Mistrik, the journalistic style - oscillating on the borderline between objective and subjective styles - is "a way of purposeful selection and thematic arrangement of those standard language means that are used for making the most up-to-date, accurate, and convincing information [intended] to the public" [9, p. 460]. Essential features of this style include written form, monological nature, publicity, and conceptuality, its specific features including information, variability, consistency, and topicality. J. Findra defines the following dominant features of the journalistic functional style as a model of the surface organization of the media text: "the public, official nature, written, monological form, absence of the addressee, communicative function" [5, p. 262]. Although in connection with the development of the electronic media the presence of the addressee may be justifiably considered.

By comparing the characteristics of the journalistic and colloquial styles, we state that they form a kind of opposition to the surface organization of the structure of the texts, since it is only the communicative function that is their shared attribute. While this is a distinctive feature in the colloquial-style texts, in the journalistic acts of communication the communicative function should be linked to the cognitive one, particularly in terms of accuracy, information load, and objectivity.

In the journalistic style, lexical means prevail, by which information are provided in an accurate and comprehensible way. Thus, the authors of the texts should avoid "special expressions, professional terms with a narrow or limited 
extent of the meaning of the word (texts of the journalistic style must be comprehensible to a wide range of recipients), but also words typical of colloquial style, i.e. ordinary, unofficial, spontaneous speeches (these, however, penetrate into emotionally tinted journalism, partly even into the rational-type journalism, including non-literary words)" [6, p. 20]. The relevant question is therefore contained in the rate of penetration of colloquiality into official media acts of communicating a message.

Focusing on the expressive means of colloquiality, we perceive colloquiality as "the property of the linguistic means occurring not just in the colloquial style, but also in other styles, specifically in the manifestations of other styles that are materialized in their oral form" [1, p. 182]. We add that the means having the attribute of colloquiality may occur not just in spoken acts of communication, but also in written acts of communication as forms of any functional language style, although the aim here is not their prototype-like application. This fact is the stimulus for our research, therefore we will focus in the analysis on the written acts of communication of journalistic style in which the presence of colloquial means of expression is marked.

\section{RESEARCH METHODOLOGY}

With regard to the extent and striking dispersion of the means of expression in the semantic subsystem of language (lexical, syntactic, and morphological levels), we focus our research intention at the lexical level. The sub-corpus of journalistic texts $^{2}$ in the current version of the Slovak National Corpus was the source text material for the analysis.

At first in the Krátky slovník slovenského jazyka (Short Dictionary of the Slovak Language) [8] we have been manually searching for all of the auto-semantic lexical units with the qualifier "hovor." (coll.), i.e. the words that are classified as colloquial. In particular, we focused on all the auto-semantic lexemes, even though we have also been searching for syn-semantics and examining the qualifier of colloquiality in them at various levels:

a) primarily at the level of lexemes (áčko, hit, krach, macher, presilovka, rámus, surfovat', zubačka 'A-class, hit, smashup, coxcomp, power play, hurly-burly, surf, cog-rail');

b) secondarily at the level of lexia or lexias (bugina $=1$. a folding stroller; citovat' 'quote' - 2. summon; diplomatka - 2. a lighter briefcase; doktor - 4 . physician; glazúra - 2. glaze; mangl'ovat'-2. beat, batter; nakladačka - 2. cucumbers

${ }^{2}$ Slovak National Corpus - prim-8.0-public-inf. Bratislava: Jazykovedný ústav L. Štúra SAV 2018. Available at: http://korpus.juls.savba.sk. There are 1009613215 tokens (791 376893 words) located in the sub-corpus of informative acts of communication. 
for pickling; odpráśsit -2 . run away, 3. expel, dust; plačka - 1. a weepy woman; vizita - 2. visit); or

c) at the level of contextual meaning in relation to the corresponding lexia (čislo 'number' - to 3. "part of the performance; one performance" fig. coll. to je čislo!; dirigent "director' - to the meaning of "who directs", coll. dirigent mužstva "director of the team'; lietaci - to the meaning of "designed, adapted to fly" coll. lietacie dvere $=$ swinging door; vizita (visit) - meaning "regular visit by a group of physicians in patient rooms", coll. "a group of such physicians").

We recorded separately homonymous colloquial lexemes as long as they were marked with the appropriate qualifier. There were mono-semantic words found in this group, such as:

$f u k^{1}-$,adv. coll. expr. in the word group to, on (mi) je f. jedno, l'ahostajné (-ý) (I don't care)";

fuk $k^{2}$ - „usually plural. coll. expr. peniaz, peniaze (money): (ne)mat' (have-not to have) $f-y^{\prime \prime}$ (KSSJ, 2003, s.169);

but also polysemantic lexical units, such as:

$b a b a^{1}$-y báb $f$.

1. coll. stará žena 'an old woman': stará b.,

2. pejor. nepríjemná, zlá, protivná žena 'unpleasant, evil, annoying woman': klebetná, zlostná b.,

3. slang. mladá žena, dievča 'a young woman, girl': $b-y z$ internátu,

4. coll. pôrodná asistentka 'childbirth assistant': pôrodná b.,

5. pejor. zbabelec, bojazlivec, slaboch 'coward, warlord, weak': nebud' b.!,

6. slepá b. children game: hrat'sa na slepú b-u and phras. sham,

$b a b a^{2}$-y báb $f$. coll.

1. empty pie,

2. harula (potato cake): zemiaková b.,

3. white grub,

4. colon sausage (KSSJ, 2003, p. 56).

Identifying the exact occurrence of polysemantic and homonymous lexemes in the corpus was problematic in part. Therefore, we have not included in the database of the lexemes searched - with regard to further word processing - the verbs with a number of lexias higher than 4 (e.g. rezat', prist', sediet' 'cut, come, sit' - the qualifier "hovor." (coll.) is only given in some lexias); sporadically, such a phenomenon also occurred with adjectives (silný, t'ažky' 'strong, heavy') or nouns (chlapec, život 'boy, life').

In this way we searched and subsequently recorded 1,770 lexical units in order to verify their occurrence in the texts of the journalistic style. Since this is an extensive material that require time-consuming processing, we are currently checking the occurrence of the first 550 lexemes (1. abonentka 'female subscriber' $\rightarrow 550$. krstřa 'god-child') in the SNK. 
In the relevant sub-corpus, we were searching for its absolute frequency of each lexical unit. However, for several multi-semantic words, it was not possible to detect the exact incidence of colloquial lexias due to polysemia or the occurrence of lexemes in case of homonymy ( $a k o r d^{2}$ - úkolová práca 'chord' - task work; baba; $b a b a^{1}, b a b a^{2}$ - non-colloquial + colloquial semes, altogether 11,249 occurrences; $b a b k a^{2}-1$. part of a hasp and staple, 2. ankle forging of scythe; cifra 'cipher' 'ornament'; citovat ${ }^{2}$ - 'summon'; cvik - 'vee'; dóza (box); huba - 'mouth', 'yap'; kopačka ${ }^{1} ;$ koštovat $^{1}$, koštovat $^{2}$ ).

A high level of homomorphism was also problematic in research, for example: áčka (As); advokát 'advocate' (= advocate in general to the basic meaning of "legal representative, attorney"); béčka 'Bs'; bežat' 'run' (3. íst', ponáhl'at' sa 'go, rush'; bláznit' sa 'be crazy' (2. show striking interest in someone, something); blázon 'fool, crazy, mad' (3. unreasonable person; crank); bledý 'pale' (3. evil, critical); bronz 'bronze' (2. bronze-coloured); céčka 'Cs'; ceremónia 'ceremony' (2. okolky 'shillyshally'; corgoň (= a grown up, big boy, young man); cukrovka (1. sugar beet); čara (= exchange); čarat', čarovat ${ }^{1}$ (= menit', vymieňat', zamieňat') (change, replace, swap); čislo (fig. coll. to je čislo! 'what a feat!' to the $3^{\text {rd }}$ meaning "part of the show, performance"); darovat ' give, donate' (2. usually in the negative of forgive - to mu nedarujem! 'I can't wink at that'; déčka 'Ds'; detská 'playroom'; dial'kar (2. who is studying part-time, 3. driver on the long distance tracks); dodávka (3. van); doktor (4. physician); éčka (Es); expresný (= coll. this was an express job to the basic meaning of "quick, fast, rapid"); fantastický (2. huge, unheard of); filmovat' (3. play a role in the film, 4. pretend); chlapec (4. = male); chlieb (2. livelihood); kontra (2. opposition in card games). These lexemes, or their colloquial semes, were not identifiable by frequency.

For many lexemes, it was necessary to work with the filtering tool or manually filter out the irregular forms that were part of the searched expression paradigm. For example, in the corpus paradigm of the lemma káro, there are also grammatical forms of other lexemes, namely the forms of the non-verbal lexemes of kára (jazdil na káre 'man rode the car'), or, alternatively, as well as the form-identical proprium (Sergej Kára) (Sergei Kára), or the searched expression occurs as part of another word (... niekolko SBS-károv na riadenie plynulosti parkovania ' ... a few security men to control the smooth flow of parking').

\section{RESEARCH RESULTS}

After searching for excerpted colloquial lexemes, we have created 8 groups of words with differentiated incidence to clarify the results of their absolute frequency in the sub-corpus of journalistic texts. The data is presented in the following table: 


\begin{tabular}{|r|l|r|}
\hline Group & ABSOLUTE FREQUENCY OF OCCURRENCE & NUMBER OF LU \\
\hline 1 & over 10000 & 18 \\
\hline 2 & $9999-5000$ & 18 \\
\hline 3 & $4999-1000$ & 61 \\
\hline 4 & $999-500$ & 34 \\
\hline 5 & $499-100$ & 132 \\
\hline 6 & 99 and less & $\mathbf{2 0 5}$ \\
\hline 7 & zero incidence & 39 \\
\hline 8 & unidentified incidence & 43 \\
\hline
\end{tabular}

Tab. 1. Groups of words in accordance to their absolute frequency

As can be seen from the above overview, the most sought-after colloquial means (205) are in the range from 1 to 99 (fotokrúžok, abonentka, filc, kancel', fotel, dvojkár, čertovina, háčko, buksa, elpéčko, kamrlik, gyps, fáč) 'photo circle, subscriber, felt, office, armchair, a student usually being awarded Bs, devilish trick, an H, box, LP, cubbyhole, gyps, bandage', in general, it is thus a relatively low incidence of colloquial words that do not disturb the course of communication, on the contrary, they functionally express the intention of the author. We add that the use of colloquial expression is determined by the theme of the act of communication and also reflected by the zero incidence of some lexemes (babra, figl'ovat', golfky, došpatit', javeru). The absence of these words in the texts of the journalistic style reflects their position in the language vocabulary. These are in fact lexical units that are located on the periphery within the lexical stratification, and thus are little used in ordinary spoken communication. In addition, one may assume their higher level of colloquiality. Compared to them, there are words with a lower level of colloquiality that are the most frequent in the journalistic texts. Such colloquial expressions include the lexemes: automobilka 'car-making factory' (46 207), inkasovat' 'cash' (28 743), chalan 'boy' (27 807), hit 'hit' (25 643), akurát 'just' (24 927), fotka 'photo' (22 639), kanonier 'canonier' (20 361), fabrika 'factory' (18 659), bytovka 'apartment building' (17 737), krčma 'pub' (15 698), fotoaparát 'camera' (14 409), kontaktovat' 'contact' (14 363), garantovat' 'to guarantee' (13 909), garancia 'guarantee' (13 029), krach 'crash' (12 965), fajn 'fine' (12 912), kilo 'kilo' (11 559), kemp 'camp' (10 365).

The words with the highest incidence were examined in the SSSJ $(2006,2011)$ to determine whether they were reclassified to neutral words or lexemes/lexias with another qualifier ${ }^{3}$. A significant change was found in 7 words, namely automobilka 'car factory', hit, bytovka (= residential house; in the case of a new, differentiated

${ }^{3}$ Since the processing of all the volumes of the Slovník súčasného slovenského jazyka (Dictionary of Contemporary Slovak Language) $(2006,2011,2015)$ is based on corpus findings, we assumed that one, though not the only one, determinant of lexicographic entries - with an impact on the classification symptoms of lexeme and their lexicon - is frequency the occurrence of the word in the SNK. 
meaning "bytová krádež" ("housing theft") the colloquiality qualifier is given), krčma, fotoaparát, kontaktovat', garancia, 'pub, camera, to contact, guarantee' that are in the current dictionary processed as non-colloquial, that is, stylistically unmarked. Conversely, as colloquial are classified the words as inkasovat' (= get a goal, blast ...), chalan, akurát, fotka, fabrika a kilo 'boy, just, photo, factory and kilo'. In some words, the qualifier changes are partial. Either the word is only colloquial in one of its meanings (e.g. garantovat' 'guarantee' - 3. coll. give a verbal guarantee; krach 'crach' -2 . loss of favourable state), or the original colloquial mark has changed to another one, signalling the use of the word or of its lexia as a professional expression (e.g.. kanonier - 2. sport. a player famous for shooting at the goal; kemp - 2. sport. professional training center).

Our research suggests that the words that are often used in journalistic acts of communication get into the core of the vocabulary, and at the same time their stylistic markedness is attenuated (see also Bosák [2], [5]). A similar tendency in the language was indicated by I. Bónová, who confirmed by research that various forms of words from the so-called common language, when used for a longer period of time, will infiltrate the standard variety and will gradually acquire a neutral stylistic validity within the dynamizing processes [3].

Thus, we may state that the frequency of incidence of the marked means of expression is a determining factor in relation to its stylistic markedness. As the frequency is decreasing, the presence of the mark of colloquiality is becoming higher. Moreover, it is not a state but a process in which markedness, e.g. colloquiality, attenuates gradually.

\section{CONCLUSION}

The subject matter of the submitted paper has been the research into lexical means with the attribute of colloquiality in journalistic texts. It turns out that the incidence of the lexemes (and lexias) examined is significant in some cases, suggesting the penetration of these elements into the field of journalistic style. However, we do not assess this fact as counterproductive, i.e. the incidence of colloquial means of expression - primarily used in interpersonal unofficial, familial communication - does not decrease the official nature of the journalistic communication, on the contrary, the authors are also "approaching" the percipient or audience in this way.

On the basis of our partial research, we may confirm the tendency to dynamize the language system, since a significant rate of use of some of the originally colloquial words leads to their reclassification into non-colloquial lexemes or lexias or to re-classifying them into terms from different areas (sport, culture, etc.). The changes that have occurred in the process of compiling a new glossary (in comparison to the KSSJ) confirm at the same time the research methodology set and mean an 
indirect feedback in relation to the relevance of examining the incidence of colloquial means of expression in the texts representing a "live language". This constantly confirms the "live speech" pressure on the status quo in the language system.

\section{ACKNOWLEDGMENTS}

This paper has been elaborated as part of the grant project No. 008UPJŠ-4/2017 Science Without Barriers (Interdisciplinary Inspirations of Contemporary Literary Scholarship and Linguistics in Educational Practice at University, Project Leader: Prof. PhDr. Ján Gbúr, CSc.).

\section{References}

[1] Bodnárová, M. (2013). Terminologická reflexia komunikácie v súkromnej sfére vo vzt’ahu k hovorovému štýlu a jemu blízkym javom - niekol'ko úvah a poznámok. Slovenská reč, 78(34), pages 174-186.

[2] Bosák, J. (1984). Hovorovost' ako dynamický faktor. Slovenská reč, 49(2), pages 65-73.

[3] Bónová, I. (2017). K problematike hovorenej podoby jazyka na východnom Slovensku. Slovenčinár, 4(1), pages 4-8.

[4] Bosák, J. (1995). Sociolingvistická stratégia výskumu slovenčiny. In Sociolingvistické aspekty výskumu súčasnej slovenčiny. Sociolinguistica Slovaca. Ed. S. Ondrejovič - M. Šimková. Bratislava, Veda, pages 17-42.

[5] Findra, J. (2013). Štylistika súčasnej slovenčiny. Martin, Osveta, 320 p.

[6] Gladiš, M. (2015). Žáner v prostredí masových médií. Košice, UPJŠ, 128 p.

[7] Ivanová-Šalingová, M. (1963). Hovorový štýl súčasnej spisovnej slovenčiny. Slovenská reč, (28), pages 17-32.

[8] Krátky slovník slovenského jazyka. (2003). Eds. J. Kačala - M. Pisárčiková - M. Považaj. $4^{\text {th }}$ amended and modified issue. Bratislava, Veda, 985 p.

[9] Mistrík, J. (1989). Štylistika. $2^{\text {nd }}$ edition. Bratislava, SPN, 584 p.

[10] Peciar, Š. (1965). Jazykové prostriedky hovorového štýlu spisovnej slovenčiny. In Jazykovedné štúdie. 8. Bratislava, Vydavatel'stvo SAV, pages 42-70.

[11] Reifová et al. (2004). Slovník mediální komunikace. Praha, Portál, 328. p.

[12] Slovník súčasného slovenského jazyka. A - G (2006). Schol. ed. K. Buzássyová - A. Jarošová. Bratislava, Veda, 1,134 p.

[13] Slovník súčasného slovenského jazyka. H - L (2011). Schol. ed. A. Jarošová - K. Buzássyová. Bratislava, Veda, $1,087 \mathrm{p}$.

[14] Slovník súčasného slovenského jazyka. M - N (2015). Schol. ed. A. Jarošová. Bratislava, Veda, $1,104 \mathrm{p}$. 